\title{
Contracting for a European Insolvency Regime
}

\author{
Horst Eidenmüller ${ }^{1}$
}

Published online: 11 July 2017

(C) The Author(s) 2017. This article is an open access publication

\begin{abstract}
The European Commission has proposed a Directive on 'preventive restructuring frameworks' for financially distressed firms. I demonstrate that the proposal is flawed because it creates a refuge for failing firms that should be liquidated, because it rules out going-concern sales for viable firms, and because it is, in essence, a twisted and truncated insolvency proceeding. I also demonstrate that the Commission's harmonisation plan is misguided. If implemented, financing costs for firms would rise. The plan would cast in stone an inefficient restructuring framework on a European-wide scale, preventing Member States from experimenting with more efficient procedures, and it would lead to more written-off loans instead of fewer non-performing loans. The Commission should withdraw its proposal. I suggest an alternative regulatory proposal: European firms should have the option to choose a 'European Insolvency Regime' in their charter. This regime should be embodied in a European Regulation, guaranteeing legal certainty to stakeholders. Firms might be given the additional option to have the regime enforced by a specialised European insolvency court. This proposal would preserve horizontal regulatory competition between the Member States for the best 'insolvency product', and it would introduce vertical regulatory competition between the Member States and the EU in the field of insolvency law. Key design principles of the proposed optional 'European Insolvency Regime' are the following: (1) it should be open for restructurings, going-concern sales, and liquidations; firms should be channelled into the appropriate process based on the opinion of a courtappointed supervisor; (2) it should be a fully specified (complete) and fully collective insolvency proceeding; (3) the proceeding should be conducted in DIP form
\end{abstract}

Horst Eidenmüller

horst.eidenmueller@law.ox.ac.uk

1 Dr iur, LLM (Cantab), MA (Oxon), Freshfields Professor of Commercial Law, University of Oxford, Oxford, UK 
with the mandatory appointment of a supervisor who performs important insolvency-related functions.

Keywords Insolvency · Bankruptcy · Restructuring · European Directive · European Regulation · Bankruptcy contracting

\section{Introduction}

It has recently been suggested that in the US 'the market sale has become a prime system of industrial restructuring'. ${ }^{1}$ It appears that the days of lengthy bargaining over the contours of a Chapter 11 reorganisation plan are over. ${ }^{2}$ Sales under 11 U.S.C. $\S 363$ occur in a significant portion if not in the majority of bankruptcies of public companies: 'Today we sell firms in bankruptcy to the highest bidder.' ${ }^{3}$ And this is not the end of the story: with the demise of large, vertically integrated conglomerates, the rise of decentralised firms that are contractually assembled from small building blocks, the bankruptcy safe harbours for derivatives, and the possibility to rapidly refinance existing debt, cornerstones of traditional bankruptcy scholarship and policy, such as the automatic stay and (temporarily) keeping the assets of a bankrupt firm together, are increasingly called into question. ${ }^{4}$

By contrast, in Europe, 'classic' corporate restructurings are still very much en vogue. Member States of the European Union (EU) are experimenting with various types of pre-insolvency or preventive restructuring proceedings that aim at refinancing financially distressed but economically viable firms. ${ }^{5}$ The idea is to have a legal framework that allows firms to readjust their capital structure well before they are in fact insolvent. The great majority of these proceedings are 'structured bargaining proceedings', meaning a proceeding whereby a debt rescheduling plan is proposed and negotiated amongst all or certain (types) of the firm's creditors, and the plan is deemed accepted and will be implemented if a majority of the creditors (as defined in the relevant statutes) votes for it.

The EU, for its part, has embraced and, indeed, spearheaded this trend. For instance, the most important new feature of the recently recast European Insolvency Regulation $(\mathrm{EIR})^{6}$ is a broadening of its scope to include pre-insolvency, debtor in possession (DIP) type proceedings that do not necessarily extend to all creditors of a debtor (recast

\footnotetext{
1 Roe (2016), at p 2.

2 And much earlier than Skeel thought, see Skeel (2001), at p 243 ('the overall approach should be good for another century').

${ }^{3}$ Roe (2016), at p 15.

4 Paterson (2015) and Roe (2016), at pp 19 et seq.

5 See Eidenmüller (2016a), Section III 1; Lin and Rosenberg (2013). For recent developments in the UK, see: The Insolvency Service, A review of the corporate insolvency framework: a consultation on options for reform, May 2016, available at https:/www.gov.uk/government/uploads/system/uploads/attachment_ data/file/525523/A_Review_of_the_Corporate_Insolvency_Framework.pdf (last visited on 8 January 2017); Payne 2016.

${ }^{6}$ Regulation (EU) 2015/848 of the European Parliament and of the Council of 20 May 2015 on insolvency proceedings, OJ L 141 of 5 June 2015, pp 19 et seq.
} 
Article 1 EIR). However, the EIR does not harmonise Member States' insolvency regimes. Instead, it merely provides a jurisdictional and private international law framework that determines where and according to which rules insolvency proceedings are to be conducted and what their cross-border effects will be.

For the European Commission, harmonising Member States' substantive insolvency and discharge regimes is the next logical step in building the European internal market: it would (purportedly) create equal refinancing conditions for all distressed businesses in Europe, wherever they are located. At the same time, undertaking this harmonisation with respect to Member States' 'traditional' insolvency regimes is sure to meet considerable political resistance. In particular, issues such as the governance of insolvency proceedings (including the role of the courts, insolvency administrators and the debtor), as well as the substantive ranking of claims are dealt with very differently across Member States, which reflects diverse regulatory traditions and contested value judgments.

Hence, it appears to be a much safer political strategy to focus on preventive corporate restructuring frameworks that can be accessed by the debtor preinsolvency. Many Member States do not have such proceedings in their insolvency rule books and, therefore, can be expected to be less resistant to a European model regime that restricts itself to early restructurings as opposed to insolvency proceedings in the more traditional, narrow sense.

Accordingly, in 2014, the European Commission issued a Recommendation on a new approach to business failure and insolvency. ${ }^{7}$ A European Recommendation is just that: a recommendation. It has no binding force on the Member States (Article 288 TFEU). However, the appetite of Member States for legislative reform based on the Recommendation was underwhelming at best. Indeed, most of the Member States, including large ones such as the UK, France, Germany and Italy, did not even react to the European Commission's initiative. ${ }^{8}$

That, of course, tells us nothing about the reasons for such passivity: whether these Member States thought they already had efficient restructuring frameworks in place, judged the Commission's proposal to be defective (by comparison), or thought that there were more pressing regulatory problems to attend to, for example. Nonetheless, without further analysis, the Commission simply assumed that Member States' passivity was unjustified and announced in its 'Action Plan on Building a Capital Markets Union', on 30 September 2015, that it

'will propose a legislative initiative on business insolvency, including early restructuring and second chance, drawing on the experience of the Recommendation. The initiative will seek to address the most important

\footnotetext{
7 Commission Recommendation of 12 March 2014 on a new approach to business failure and insolvency, $\operatorname{COM}(2014) 1500$ final. For an analysis of the Recommendation, see Eidenmüller and van Zwieten (2015).

${ }^{8}$ See Directorate-General Justice \& Consumers of the European Commission, Evaluation of the implementation of the Commission Recommendation of 12 March 2014 on a new approach to business failure and insolvency, 30 September 2015, available at http://ec.europa.eu/justice/civil/files/evaluation_ recommendation_final.pdf (last visited on 1 January 2017).
} 
barriers to the free flow of capital, building on national regimes that work well." 9

Now, a little more than a year later, this initiative has been launched. On 22 November 2016, the Commission published a Proposal for a Directive of the European Parliament and of the Council on preventive restructuring frameworks, second chance and measures to increase the efficiency of restructuring, insolvency and discharge procedures and amending Directive 2012/30/EU. ${ }^{10}$ The stated objective of the Directive is to

'remove obstacles to the exercise of fundamental freedoms, such as the free movement of capital and freedom of establishment, which result from differences between national laws and procedures on preventive restructuring, insolvency and second chance. This Directive aims at removing such obstacles by ensuring that viable enterprises in financial difficulties have access to effective national preventive restructuring frameworks which enable them to continue operating.' (Recital 1)

At the same time, the envisaged restructuring frameworks 'should also prevent the build-up of non-performing loans' (Recital 2), which will (allegedly) give banks greater flexibility to finance (more) profitable projects and firms.

In this paper, I analyse the Commission's proposal and challenge its rationale and merits. To begin, I demonstrate that the Commission's case for harmonisation of Member States' pre-insolvency restructuring regimes is unconvincing at best. Specifically, I demonstrate that financing costs for businesses will not be reduced by access to a preventive restructuring framework as envisaged by the Commission. Rather, if anything, these costs stand to rise if the Commission's proposal is adopted. I further demonstrate that the restructuring framework envisaged by the Commission is seriously flawed for several reasons (which is one of the causes of higher financing costs under the framework). It is flawed because it creates a refuge for failing firms that should be liquidated. The overwhelming majority of firms in financial distress fall into this category. The Commission's proposal is also flawed because it rules out going-concern sales for viable firms, and such sales are usually a much more efficient process to restructure viable firms and keep them alive. Finally, the Commission's proposal is flawed because it is, in essence, a twisted and truncated insolvency proceeding. It looks like a Chapter 11 proceeding without strong court involvement from the beginning and without the tools needed for the court to guarantee a fair outcome of the process.

In light of these deficiencies, I suggest that the Commission should withdraw its proposal, and should instead propose a Regulation (not a Directive) for an optional

\footnotetext{
9 Communication from the Commission to the European Parliament, the Council, the European Economic and Social Committee and the Committee of the Regions: Action Plan on Building a Capital Markets Union, COM(2015) 468 final, 30 September 2015, available at http://ec.europa.eu/finance/ capital-markets-union/docs/building-cmu-action-plan_en.pdf (last visited 1 January 2017), at p 25.

${ }^{10} \operatorname{COM}(2016) 723$ final, available at http://ec.europa.eu/information_society/newsroom/image/ document/2016-48/proposal_40046.pdf (last visited 1 January 2017). For an initial assessment of the proposal, see Eidenmüller and van Zwieten (2016).
} 
European Insolvency Regime. Under such a Regulation, firms would be able to opt into the regime in their charter, thereby contracting for a European Insolvency Regime. Firms might be given the additional option to have the regime enforced by a specialised European insolvency court. I also sketch how the main features of such an optional European Insolvency Regime should look. This proposal has two key advantages compared to the approach currently pursued by the Commission: first, a Regulation would really achieve harmonisation - if a firm opted into the European insolvency framework, it could be certain that this framework would be applied in an insolvency situation. By contrast, a European Directive will only partially harmonise Member States' pre-insolvency restructuring frameworks. Second, and more importantly, offering an optional 29th (or 28th after Brexit) insolvency regime would maintain regulatory competition between the Member States horizontally and between the Member States and the EU vertically for the best 'insolvency product'. By contrast, if the Member States' pre-insolvency restructuring laws were harmonised according to the Commission's proposal, regulatory damage would be done on a grand scale-an inefficient procedure would be forced upon all Member States without market forces operating as a potential corrective.

The foregoing is elaborated in the sections that follow. In Sect. 2, I present the Commission's case for a European Restructuring Directive (RD) and the main elements of the Commission's proposal. In Sect. 3, I critique the Commission's harmonisation plan as being misguided and the draft RD as being seriously flawed. In Sect. 4, an alternative regulatory proposal is developed. Namely, I suggest that firms be given the possibility to opt into a European Insolvency Regime that is contained in a European Regulation. Section 5 concludes with a summary of the main results of the paper and an outlook on future developments in regulating corporate restructurings.

\section{The Draft European Restructuring Directive}

To begin, it is necessary to describe the rationale and the key elements of the draft RD. In particular, as will be seen, when considering a harmonisation measure with respect to Member States' insolvency laws, the European Commission faced a twofold task: it had to make a case for a specific form of harmonisation, namely, minimum harmonisation by a European Directive; and it had to make a case for specific contents of the proposed harmonisation measure, namely, an instrument that provides a framework for a pre-insolvency preventive restructuring proceeding. How the Commission addressed these tasks is described below.

\subsection{The Case for Harmonisation}

The European Commission's case for harmonisation primarily rests on a thesis that links access to an (allegedly) efficient pre-insolvency preventive restructuring framework with lower financing costs for European businesses, especially SMEs. ${ }^{11}$ Simply put, the Commission's thesis is as follows: (1) financing costs of firms are a

$\overline{{ }^{11} \operatorname{COM}(2016)} 723$ final, at pp 2, 5-7, 14-15. Recitals 1-2, 13 of the proposed RD. 
function of recovery rates for lenders in bankruptcy-the higher these recovery rates, the lower the financing costs; (2) (allegedly) efficient pre-insolvency restructuring proceedings maximise recovery rates for creditors; (3) it is therefore important that firms in Europe have access to such proceedings regardless of where they are located-large listed firms are able to cross-border forum shop for an efficient restructuring regime in another European jurisdiction, SMEs will not enjoy this opportunity; and thus, (4) the European lawmaker must harmonise preinsolvency restructuring proceedings so that all European firms benefit from lower financing costs.

The second leg of the Commission's case for a European instrument on preventive restructuring frameworks rests on an identified problem with nonperforming loans. According to statistics produced by the European Central Bank, as of Q2 2016, more than EUR 936bn loans in the banking system were characterised as non-performing. ${ }^{12}$ For the Commission, this constitutes a serious problem: 'Such loans weigh heavily on banks' capacity to finance the real economy in several Member States.' ${ }^{13}$ Preventive restructuring frameworks in place in the Member States would, it is hoped, help reduce the volume of non-performing loans, giving banks more flexibility and freedom to finance (profitable) projects and firms.

The Commission's proposal gives very little attention to regulatory strategies and tools. Are the identified problems serious enough to do something, or should the status quo be maintained? If action is taken, should it be in the form of a Directive or by a Regulation? ${ }^{14}$ Should the chosen instrument contain options, and if so, for whom (Member States, private actors, etc.)? Should harmonisation be in the form of minimum standards that allow Member States to go beyond the stipulated provisions, or should a fully harmonised framework be proposed? The Commission feebly attempts to answer all these questions in one sentence: 'A binding instrument in the form of a Directive setting up a minimum harmonised framework appears necessary to achieve the policy objectives on restructuring, insolvency and second chance. ${ }^{15}$ Admittedly, slightly more detail can be found in an impact assessment study that was contracted by the Commission to a group of authors representing business/legal/policy consulting firms and published shortly after the release of the draft RD. ${ }^{16}$ However, the discussion in this study also is superficial,

\footnotetext{
12 European Central Bank, Supervisory Banking Statistics-Second Quarter 2016, November 2016, available at https://www.bankingsupervision.europa.eu/ecb/pub/pdf/supervisorybankingstatistics_ second_quarter_2016_201611.en.pdf (last visited on 2 January 2017), at p 70. The corresponding figure in Q2 2015 was EUR 988bn, i.e., there is a clear downward trend. The problem is most acute in Greece, Cyprus, Portugal and Italy, with non-performing loans ratios of 46, 41, 20 and 16\%, respectively.

$13 \operatorname{COM}(2016) 723$ final, at $\mathrm{p} 12$.

14 According to Article 288 TFEU, '[a] regulation shall have general application. It shall be binding in its entirety and directly applicable in all Member States. A directive shall be binding, as to the result to be achieved, upon each Member State to which it is addressed, but shall leave to the national authorities the choice of form and methods.'

$15 \operatorname{COM}(2016) 723$ final, at p 16 (emphasis added).

${ }^{16}$ Hausemer $\mathrm{P}$ et al., Impact assessment study on policy options for a new initiative on minimum standards in insolvency and restructuring law_final report, November 2016, available at http://ec.europa. eu/information_society/newsroom/image/document/2016-48/final_report_formatted_jiipib2_for_ publication_40116.pdf (last visited on 2 January 2017), at pp 64-100.
} 
methodologically unsound ${ }^{17}$ and, in any case, is clearly driven by the motive of supporting the Commission's preferred regulatory course.

\subsection{The Proposed Preventive Restructuring Framework}

In its draft RD, the European Commission proposes harmonisation of two areas of substantive Member State law: the rules governing the restructuring of financially distressed business debtors (Title II), and aspects of the rules governing the treatment of bankrupt entrepreneurs, particularly the time to discharge after commencement of bankruptcy proceedings (Title III). Additionally, the Commission proposes a series of measures to enhance the efficiency of insolvency rules and procedures more generally (Title IV), and new measures to improve the collection and publication of data on national insolvency procedures (Title V). This paper focuses on Title II as applied to financially distressed corporate debtors.

Title II of the draft RD begins by stating that access to an 'effective preventive restructuring framework' must be made available to debtors in financial difficulty once there is a 'likelihood of insolvency' (Article 4(1)). What is meant by 'likelihood' is not further specified in the draft RD, which is unfortunate as there always is ' $a$ ' likelihood of insolvency, however small. A reasonable construction might be an assessment according to which there is a greater than $50 \%$ probability that the debtor becomes insolvent on a cash flow basis in the reasonably foreseeable future, e.g., within the next year. Member States are well advised to come up with an entry test that is as certain as possible so as to avoid costly disputes already at the entry stage of the proceeding.

Further, where the draft RD speaks of 'restructuring' it means 'financial restructuring' (see Article 2(2)). In contrast, little in the proposal suggests that some form of economic restructuring (e.g., modification of the business model, cost reductions, etc.) might be necessary to get the distressed business back on track to profitability. ${ }^{18}$ This is problematic since financial distress usually has an economic cause, and relieving this distress without addressing the underlying cause is similar to prescribing sufficiently strong painkillers to a patient so that he or she stops complaining - whatever the underlying disease. This deficiency is compounded by the fact that whoever proposes a restructuring plan-there are no rules on who has the right to do so in the draft RD—has just to provide a 'reasoned statement' that the 'business is viable' (Article $8(1)(\mathrm{g})$ ). As a result, the 'preventive restructuring framework' envisaged by the Commission should more appropriately be called the 'financial reengineering framework'.

Next, access to the framework requires an 'application by debtors, or by creditors with the agreement of debtors' (Article 4(4)). The draft RD does not foresee the

\footnotetext{
17 To give just one example: the authors were soliciting opinions of interviewees on costs and recovery rates under a European restructuring regime without having any idea about the features of such a regime. In essence, they were asking about costs and recovery rates under a procedure that was not specified at all: Hausemer et al., supra n. 16, at pp 64-65, 74-77.

18 Article 2(2) mentions 'sales of assets or parts of the business'. However, it does so only in the context of a financial restructuring of the 'debtor's capital structure', not as an element of an economic restructuring.
} 
involvement of a 'judicial or administrative authority' at the application stage (see Article 4(3)). Similarly, the draft RD does not foresee that restructuring proceedings are formally 'opened' (by a court or administrative authority). ${ }^{19}$ Thus, apparently, it suffices if the debtor simply declares that there exists a 'likelihood of insolvency' when filing the application. This result is surprising since the Commission's plan was and still is that the recast EIR and the proposed restructuring framework dovetail perfectly. However, if a Member State adopted a procedure as foreseen in the draft RD, such a procedure would be within the scope of Article 1 EIR as recast, ${ }^{20}$ and a cornerstone of the EIR (as made and as recast) is that a 'judgment opening insolvency proceedings' is necessary for a proceeding to be universally recognised in all other Member States (Article 19(1) EIR). As such, there is a clear tension between the draft RD and the recast EIR.

A proceeding under the draft RD is, in principle, a DIP proceeding. In this respect, Title II provides that the appointment 'of a practitioner in the field of restructuring shall not be mandatory in every case' (Article 5(2)). However, the draft RD further provides that Member States may require such an appointment where the debtor is granted a general stay of individual enforcement actions in accordance with Article 6 or where the restructuring plan needs to be confirmed by a judicial or administrative authority by means of a cross-class cram-down, in accordance with Article 11 (Article 5(3)).

Two long provisions in the draft RD are devoted to the stay of individual enforcement actions and the consequences of such a stay: Articles 6 and 7. Member States are obliged to introduce rules that allow a stay to be ordered in respect of all types of creditors, including secured and preferential creditors (but not workers), which may last up to twelve months if 'necessary to support the negotiations of a restructuring plan' (Article 6). ${ }^{21}$ Filing obligations with respect to domestic insolvency procedures are suspended for the duration of a stay (Article 7(1)), and a general stay covering all creditors shall prevent the opening of such insolvency procedures (Article 7(2)). Creditors to which the stay applies are also prevented from modifying executory contracts (Article 7(4)), and creditors generally may not rely on ipso facto clauses to achieve such a modification based on some restructuring-related event (Article 7(5)). ${ }^{22}$

Perhaps the most significant feature of the preventive restructuring framework envisaged by the European Commission is its 'structured bargaining proceeding', which, as described in Sect. 1 supra, means a proceeding whereby a debt-

\footnotetext{
19 See Recital 18 of the draft RD: 'Furthermore, there should not necessarily be a court order for the opening of the restructuring process which may be informal as long as the rights of third parties are not affected.'

20 See $\operatorname{COM}(2016) 723$ final, at p 9.

21 According to Article 6(1), a four-month stay may be imposed under these conditions. The stay can be extended according to Article 6(5)-(7) up to twelve months if 'relevant progress' has been made in these negotiations, the continuation of the stay does not 'unfairly prejudice the rights or interests of any affected parties' and the circumstances of the case 'show a strong likelihood that a restructuring plan will be adopted'.

22 However, according to Article 7(6), creditors that are not affected by the restructuring or claims by affected creditors that arise after the stay is granted are not subject to the prohibitions in Article 7(4)-(5).
} 
rescheduling plan is proposed and negotiated amongst all or certain (types) of the firm's creditors. There is nothing in the proposal that foresees a liquidation of the business. Likewise, there is nothing in the proposal that foresees a going-concern sale of the whole business to an investor. The definition of 'restructuring' in Article 2(2) leaves room only for a financial restructuring that includes 'sales of assets or parts of the business, with the objective of enabling the enterprise to continue in whole or in part' (emphasis added).

It is for the proposer of a restructuring plan to decide which (types of) claims to include in the plan and which to exclude. Moreover, affected claims shall be grouped in separate classes to ensure that only 'sufficiently similar' claims are grouped together (Article 9(2)). Secured and unsecured claims must always be treated in separate classes (Article 9(2)).

A crucial technique in financial restructurings are debt-to-equity swaps (DES). They reduce a distressed firm's fixed liabilities and strengthen its equity base. Important scholarly contributions on reforming bankruptcy reorganisations are based on swapping all or significant portions of a firm's debt for (call options on) equity positions. ${ }^{23}$ Many corporate bankruptcy statutes world-wide provide for DES by stipulating that shareholders' claims may be grouped in (a) separate class(es), and shareholders vote on the plan, as do creditors. This is true, for example, of Chapter 11 in the US (11 U.S.C. $\S 1123(a)(1), \S 1141(d)(1)(B)$ ), and of the insolvency plan procedure according to sections 217 and 225a of the German Insolvenzordnung. ${ }^{24}$ Conceptually, classifying shareholders as lowest-ranking creditors makes sense: they have a claim on the remaining assets of a distressed firm only if all higher-ranking creditors can be paid in full.

The treatment of shareholders in the Commission's proposal appears peculiar at first sight. Article 12(1) provides that Member States must ensure that 'shareholders and other equity holders... may not unreasonably prevent the adoption or implementation of a restructuring plan'. A restructuring plan may include changes in 'the debtor's capital structure, including share capital' (Article 2(2)-emphasis added). ${ }^{25}$ Article $12(2)$ then stipulates that

' $[\mathrm{t}$ ]o achieve the objective in paragraph 1, Member States may provide that equity holders are to form one or more distinct classes by themselves and be given a right to vote on the adoption of restructuring plans. In this case, the adoption and confirmation of restructuring plans shall be subject to the crossclass cram-down mechanism provided for in Article 11.' (emphasis added)

These provisions do not necessarily imply that a DES or other equity capital measures (nominal equity capital reductions, capital increases, etc.) can only be part of a

\footnotetext{
23 See, for example, Bebchuk (1988).

24 This procedure was modelled on a proposal by Eidenmüller and Engert (2009), at pp 549 et seq.

25 According to provisions in the Second Company Law Directive (Directive 2012/30/EU of 25 October 2012, OJ L 315 of 14 November 2012, pp 74 et seq.), the incumbent shareholders must vote in a shareholders' meeting on capital reductions and increases and the exclusion of pre-emptive rights. The draft RD contains a provision according to which Member States shall derogate from these provisions to the extent necessary for the establishment of the preventive restructuring framework provided for in the RD (Article 32).
} 
restructuring plan if a Member State makes use of the option provided for in Article 12(2). Member States could also allow DES or other changes in the equity capital structure of the distressed firm without shareholder participation in the plan adoption process. In order to protect the remaining value of the shareholders' property rights, ${ }^{26}$ Member States would need to establish a proceeding that allows shareholders whose interests are wiped out to claim the value of their entitlement: the restructuring value of the firm minus the nominal value of all creditors' claims. ${ }^{27}$ However, compared to this 'solution', making use of the Article 12(2) option appears to be the more coherent approach by treating the incumbent shareholders as residual claimants on the firm's assets and giving them a say (and a vote) in the restructuring process.

The bottom-line of the provisions regarding plans and approval is that consensual corporate restructurings are a possibility, but an unlikely one. Indeed, the Commission's restructuring proposal contains elaborate provisions on how restructuring plans can be put into effect if single creditors or classes of creditors object. The draft RD stipulates that a plan

'shall be deemed to be adopted by affected parties, provided that a majority in the amount of their claims or interests is obtained in each and every class. Member States shall lay down the required majorities for the adoption of a restructuring plan, which shall be in any case not higher than $75 \%$ in the amount of claims or interests in each class.' (Article 9(4))

Thus, whereas access to the preventive restructuring framework is supposed to take place with only minimal involvement of a court or administrative authority, things change dramatically if a plan is contested. According to Article 9(3), '[c]lass formation shall be examined by the judicial or administrative authority when a request is filed for confirmation of the restructuring plan'. If a creditor challenges a plan, it can be confirmed only if it meets the 'best interest of creditors test': no dissenting creditor must be made 'worse off under the restructuring plan than the or she] would be in the event of liquidation, whether piecemeal or sale as a going concern' (Articles 2(9), 10(2)(b), 13(1)). ${ }^{28}$ For these purposes, the competent judicial or administrative authority is tasked with establishing a 'liquidation value' of the business (Article 13(1)). To accomplish this task, the competent authority has to determine the hypothetical outcome of a piecemeal liquidation but also that of a sale of the distressed business as a going concern (Recital 30).

Even more sophisticated valuations are necessary if a 'cross-class cram-down' proves necessary, i.e., a 'confirmation by a judicial or administrative authority of a restructuring plan over the dissent of one or several affected classes of creditors' (Article 2(8)). Such confirmation requires that at least one affected class that is 'in the money' has approved the plan, that any new financing foreseen by the plan is necessary to implement it and does not unfairly prejudice the interests of creditors,

\footnotetext{
26 Article 1 (Protection of Property) of the Protocol to the Convention for the Protection of Humans Rights and Fundamental Freedoms; Article 17 (Right to Property) of the Charter of Fundamental Rights of the European Union.

27 Eidenmüller and Engert (2009), at pp 549 et seq.

28 The model for this provision is 11 U.S.C. $\S 1129(\mathrm{a})(7)$.
} 
and that the plan complies with both the best interest of creditors test and the absolute priority rule (Article 11(1)). Under the latter rule, 'a dissenting class of creditors must be satisfied in full before a more junior class may receive any distribution or keep any interest under the restructuring plan' (Article 2(10)). ${ }^{29}$

Plan confirmation by applying a cross-class cram-down and the absolute priority rule also forces the competent judicial or administrative authority to determine an 'enterprise value' of the business (Article 13(2)). This is not defined in the draft RD. Usually, 'enterprise value' is understood to be an economic measure reflecting the market value of a business. It is the sum of claims by all claimants: creditors (secured and unsecured) and shareholders (preferred and common). Recital 30 of the draft RD provides some more clues:

'[T]he enterprise valuation..., as opposed to the going-concern liquidation valuation of the enterprise, looks at the value of the debtor's business in the longer term. The enterprise valuation is, as a rule, higher than the goingconcern liquidation value because it captures the fact that the business continues its activity and contracts with the minimum disruption, has the confidence of financial creditors, shareholders and clients, continues to generate revenues and limits the impact on workers.'

Apparently, the competent judicial or administrative authority would have to engage in some form of discounted cash flow analysis to compute the restructured firm's enterprise value - certainly not an easy task, even for bankers.

Restructuring a financially distressed firm cannot usually be accomplished by only modifying existing claims. The firm will probably also need fresh money. Hence, the draft RD contains several provisions on both 'new financing' (Article 2(11)) and 'interim financing' (Article 2(12)). In particular, it states that 'new financing' can be foreseen in a restructuring plan (Article 8(1)(f)(iii)) if it 'is necessary to implement the restructuring plan and does not unfairly prejudice the interests of the creditors' (Article $10(2)(c))$. Whether this condition is met will have to be decided by the competent judicial or administrative authority when confirming the restructuring plan.

Moreover, and of crucial importance, is the protection afforded to 'new financing' and 'interim financing' under the draft RD. Specifically, Article 16 contemplates that such financing 'shall not be declared void, voidable or unenforceable as an act detrimental to the general body of creditors in the context of subsequent insolvency procedures' (Article 16(1)), that Member States may grant new or interim financiers a priority status in subsequent liquidation procedures (Article 16(2)), and that " $\mathrm{t}$ ] he grantors of new financing and interim financing in a restructuring process shall be exempted from civil, administrative and criminal liability in the context of the subsequent insolvency of the debtor, unless such financing has been granted fraudulently or in bad faith' (Article 16(3)).

In reviewing the position of financial creditors, such as banks, under the proposed preventive restructuring framework, several points should be noted: (1) the proposal is silent on the ranking of claims in general and on whether secured creditors enjoy a priority position in particular; (2) a stay of up to twelve months may be imposed on

29 The model for this provision is 11 U.S.C. $\S 1129$ (b). 
creditors, including secured creditors, without further conditions such as interest payments, etc.; (3) creditors, including secured creditors, may not use ipso facto clauses to terminate or otherwise modify executory contracts (as noted above); and (4), creditors, including secured creditors, may be forced to accept a restructuring plan that reduces their claims provided they fare no worse than in a liquidation of the business and the absolute priority rule is observed. The content of the absolute priority rule, i.e., which claims are senior and which are junior, is for the Member States to decide (see (1) supra).

Finally, as already mentioned, the proposed preventive restructuring framework contains 'minimum standards' only (see Recital 10), and it is cast in the legal form of a European Directive. This has important consequences for the degree of harmonisation that can or will be achieved by the instrument. First, even though the proposed RD is fairly detailed, many crucial issues are left to the Member States to determine. This includes, for example, the definition of 'likelihood of insolvency' as the crucial entry test for a restructuring proceeding, the ranking of claims in such a proceeding, who may propose a restructuring plan, the precise majority requirements that must be fulfilled for a restructuring plan to be eligible for court sanction, the precise ranking of new and intermediate financing in subsequent liquidation procedures, and many other issues. Second, it lies in the nature of a European Directive that 'it shall be binding, as to the result to be achieved, upon each Member State to which it is addressed, but shall leave to the national authorities the choice of form and methods' (Article 288 TFEU). Hence, Member States have some flexibility as to how exactly they transpose the mandates of the RD. Third, it is completely unclear what further harmonisation going beyond the 'minimum requirements' could or would mean. In short, if the draft RD were to be adopted, the overall result would be likely to be quite far from a 'harmonised' position.

\section{A Critique of the European Commission's Proposal}

Having set out the European Commission's case for the draft RD, and its main substantive aspects, I now proceed to critique the draft RD. In this regard, I will demonstrate that the restructuring framework envisaged by the Commission is seriously flawed and that the Commission's case for harmonisation of Member States' pre-insolvency restructuring regimes is weak at best. My critique is based on a few basic principles of regulatory goals and tools in corporate insolvency law. ${ }^{30}$

\subsection{Regulatory Goals and Tools in Corporate Insolvency Law}

Three basic regulatory goals and tools in corporate insolvency law are important for the purposes of this paper. $^{31}$ First, a financially distressed firm should be

\footnotetext{
30 Section 3.1 further develops points made in Eidenmüller and van Zwieten (2015), at pp 654-656.

31 These goals and tools relate to the ex post efficiency of corporate insolvency laws. The ex ante effects are, relatively speaking, more important as they capture all firms (and not just a subset of firms), see White (1996). The draft RD relates ex post and ex ante efficiency by asserting that higher recovery rates will lead to lower financing costs. Unfortunately, the RD, if implemented, would lead to lower recovery rates, see Sect. 3.3 infra.
} 
restructured and kept alive only if it is economically viable, i.e., if it does not suffer from financial and economic distress. The overwhelming majority of financially distressed firms are also economically distressed and should be liquidated. Financial distress always has a cause, and in the overwhelming majority of cases this cause is economic failure. From 1999 to 2012, for example, the German insolvency plan procedure, which is modelled on Chapter 11 in the US, was consistently used in only approximately $2 \%$ of all business insolvencies. ${ }^{32}$ That means that $98 \%$ of the businesses that filed for insolvency were liquidated-either piecemeal or via a going-concern sale. While the German restructuring proceeding may not be perfect, one can nevertheless safely assume that it does not suffer from fundamental design defects which would account for this percentage distribution: an insolvent debtor will file an insolvency plan in his own interest if he sees the slightest chance for a restructuring.

The situation in other European Member States is somewhat less extreme compared to that in Germany, but the general statement still holds: the overwhelming majority of financially distressed businesses should be and are in fact liquidated. The liquidation rate in France in 2016 was at approximately $70 \%,{ }^{33}$ in the UK in the same year close to $90 \%,{ }^{34}$ in Spain in 2015 approximately $90 \%,{ }^{35}$ and in Italy in 2014 higher than $95 \% .^{36}$ While it is true that observed actual liquidation rates are no (conclusive) evidence for how many firms should be liquidated (because they are non-viable), it certainly would be missing economic reality to assume that the observed liquidation rates in these countries in particular result from a lack of functioning restructuring proceedings. Similar to Germany, the UK, France, Spain and Italy belong to the European jurisdictions with the most elaborated restructuring codes and practices.

The conclusion to be drawn is simple: only very few European businesses should be restructured and maintained as a going concern if they suffer from financial distress, and insolvency procedures have an important 'filtering function' to fulfil: non-viable firms should be identified, and they should be liquidated as efficiently as possible.

Second, if a firm is, in principle, economically viable in whole or in part, it should be maintained as a going concern-with such changes to its business model and/or operations as are warranted under the circumstances. The lawmaker should strive to maximise the net asset value that, in principle, can be distributed amongst the firm's creditors. Incentives should be put in place so that restructuring efforts are undertaken earlier rather than later. The earlier restructuring measures are implemented, the higher the (remaining) going-concern value of the firm will be.

\footnotetext{
32 See Schultze and Braun (2014), at pp 37-38.

33 See https://www.insol-europe.org/technical-content/national-insolvency-statistics-france (last visited on 3 January 2017).

34 See https://www.gov.uk/government/uploads/system/uploads/attachment_data/file/562493/Q3_2016_ statistics_release_-_commentary.pdf (last visited on 3 January 2017).

35 See Tirado (2017).

36 See https://www.cervedgroup.com/documents/10156/105548/OsservatorioFallimentiPocedure ChiusureImpresa1q2014_en.pdf (last visited on 3 January 2017).
} 
Whether the firm should be restructured as a business in the hands of the legal entity that set it up in the first place or sold to an investor as a going concern depends on the circumstances of the individual case. In the majority of cases, going-concern sales will maximise the net asset value: they can usually be implemented fast and at relatively low costs (e.g., no structured bargaining amongst the firm's creditors, no difficult valuations necessary, etc.). But sometimes there may be no market for distressed firms, or the legal entity that runs the business owns 'dedicated assets' such as favourable contracts, licences, permits or tax loss carry-forwards that cannot (easily) be transferred to a new legal entity.

Third, insolvency procedures should contain safeguards against abuse by one stakeholder/constituency seeking to extract wealth at the expense of others. Such strategic actions are problematic (costly) if they are not anticipated and fully priced ex ante-which they never will be. As a consequence, restructuring procedures would only be predicted to reduce investment costs ex ante if such oppression ex post could be controlled-which is why certain procedural safeguards are necessary, calling for some degree of formality and transparency, supervision by neutral and competent experts, and judicial review.

These concerns are fuelled by the restructuring practice in the US in the last two decades. What appears, on the books, to be a procedure in which the debtor is in possession has shifted to become a 'power base' for sophisticated and secured financial creditors - the 'secured party in possession'. In the US, '[t]he board may be in the saddle, but the whip is in the creditors' hands' ${ }^{37}$ It appears that the par conditio creditorum is threatened, company assets are depleted before a Chapter 11 filing, and such filings take place later than used to be the case historically. ${ }^{38}$

\subsection{The Flawed Preventive Restructuring Framework}

How does the Commission's proposed 'preventive restructuring framework' fare against the background of these regulatory goals and tools? When attempting to evaluate the Commission's proposal, one needs to bear in mind that it comes in the form of a Directive containing 'minimum standards': Member States enjoy a certain regulatory flexibility with respect to implementing the RD's provisions, they can fill gaps, and may go beyond the requirements of the RD (see Sect. 2.2 supra). Hence, in the following I will focus on design defects in the European Commission's proposal that cannot be remedied during the process of implementation of the RD by the Member States. ${ }^{39}$

\footnotetext{
37 Baird and Rasmussen (2003), at p 699.

38 Adler et al. (2006), Lubben (2004), Ayottee and Morrison (2009) and Baird and Rasmussen (2010).

39 One could of course be stricter: even a defective Directive that can be 'remedied' by the Member States is not really satisfactory. Requiring Member States to 'remedy' design defects, and potentially to come up with diverging solutions both in terms of content and the extent to which they remedy such defects, appears quite problematic.
} 


\subsubsection{A Refuge for Failing Firms}

The Commission's proposal is about financial restructurings of distressed businesses, and nothing else. Indeed, the only time 'liquidation of non-viable enterprises' is mentioned in the draft RD is in the Recitals-Recitals 2 and 39-and nowhere in the substantive provisions of the draft RD. Recital 2 states that ' $[\mathrm{N}]$ onviable businesses with no prospect of survival should be liquidated as quickly as possible'; and Recital 39 stipulates 'It is necessary to maintain and enhance the transparency and predictability of the procedures in delivering outcomes that are favourable for the preservation of businesses and for giving entrepreneurs a second chance or that permit the efficient liquidation of non-viable enterprises.'

However, not a single provision in the draft RD regulates how such non-viable businesses should be identified and how (in which process) they should be liquidated. The draft RD appears to completely rely on the judgment of the proposer of the plan that the business is viable, for the plan proposal needs to be accompanied by 'an opinion or reasoned statement by the person responsible for proposing the restructuring plan which explains why the business is viable' (Article $8(1)(\mathrm{g})$ ). It appears that this 'opinion or reasoned statement' must be taken at face value and that Member States are bound by this decree of the European lawmaker.

It is not difficult to predict what will happen in practice if the RD were adopted by the European Union and implemented by the Member States: we could expect a 'restructuring rush'. Put yourself in the shoes of an entrepreneur who runs a nonviable business in a highly competitive industry threatened by digitisation and automation, say a local bookstore run by your family for generations. Sales are down, costs are increasing (rent, wages, etc.). Financial distress is around the corner. You can of course liquidate the business out of court. You can also wait until you are in fact insolvent and then file for an insolvency procedure in which the company will be liquidated. But you now have access to the new 'preventive restructuring framework'.

Rushing into this new procedure has much attraction. Court involvement is limited (Article 4(3)), and you are reasonably confident that you stay in control and that no insolvency administrator is appointed (Article 5). You are also reasonably confident that you will get the benefit of a stay for a couple of months (Article 6). While your main creditor, a commercial bank that operates nationwide, is sceptical, some of your creditors are also local firms threatened by the 'new economy' (local service companies, suppliers, etc.), and they support your restructuring plan. If you get the stay, no insolvency proceedings may be opened, and you have no filing obligations (Article 7(1) and (2)). Thus, your brother, an accountant, prepares the restructuring plan and firmly believes that the business is, in principle, viable (Article $8(1)(\mathrm{g})$ ). Of course, your plan might not be approved by the necessary creditor majorities or might fail to be sanctioned by the competent court or judicial authority. But at least it is worth a try: you access the preventive restructuring framework because that gives you an option to possibly continue with your business, and, no matter what, it certainly buys you time.

Recall that the overwhelming majority of firms that find themselves in or near financial distress are in the same position as your local bookstore: they are also 
economically distressed and should be liquidated (Sect. 3.1 supra). The European Commission's proposal will attract these firms like the light attracts mosquitoes. They will linger in the 'preventive restructuring framework' for some time and either indeed be restructured finally - but, per definition, without any viable longterm business prospects - or be singled out more or less accidentally as failing firms and eventually be liquidated. ${ }^{40}$

The Commission's proposal completely misses economic reality and the important filtering function that insolvency laws must fulfil: to restructure only viable firms and liquidate the non-viable ones. The economic costs resulting from this mistake are surely not trivial. ${ }^{41}$ This design defect alone justifies the verdict that the Commission's 'preventive restructuring framework' is an inefficient instrument for the treatment of financially distressed firms.

\subsubsection{The Neglect of Going-Concern Sales}

The second design flaw of the Commission's 'preventive restructuring framework' is its complete neglect of going-concern sales as an efficient instrument to accomplish a value-preserving restructuring. ${ }^{42}$ In the draft RD, a business's hypothetical 'sale as a going concern' is relevant only when applying the best interest of creditors test, i.e., when a competent judicial or administrative authority has to determine whether an objecting creditor fares worse under the restructuring plan compared to a liquidation of the business or a (hypothetical) 'sale as a going concern' (see Article 2(9)). The draft RD rules out an actual 'sale as a going concern' as a restructuring technique.

This is very unfortunate. As is well-known, critics of Chapter 11 have questioned for decades whether a complicated structured bargaining proceeding is worth its costs, given that selling the firm as a going concern to an investor is a viable alternative ${ }^{43}$ : it usually can be done much faster and more cheaply (lower transactions costs) than a Chapter 11 restructuring plan process, and it uses the market to value the distressed business instead of burdening the competent court with sophisticated valuation tasks. And, if there is potential acquisition interest from more than one investor, even a valuemaximising auction might be conducted. Recent empirical evidence from Sweden confirms the efficiency of 'bankruptcy auctions'. 44

\footnotetext{
${ }^{40}$ Even in the US with its highly specialised and professional bankruptcy courts, many doubt whether these courts are well positioned to properly perform this filtering function. See, for example, Miller (2002), at p 1988 ('The bankruptcy court does not possess the resources or the capacity to undertake an independent financial and operational analysis of a plan's feasibility. In judging the feasibility of the proposed reorganization, as required by the Bankruptcy Code, the bankruptcy court is a captive of the principal parties (e.g., the debtor, the creditors' committee, and the secured creditors) and the professionals retained by the parties.').

41 For an empirical study on the costs of 'inefficient going concerns', see Franks and Loranth (2005) (based on a sample of Hungarian firms).

42 This point elaborates on Eidenmüller and van Zwieten (2015), at pp 653-654.

43 See Baird (1986). See also Roe (2000), at pp 145 et seq., 577 et seq.

44 See Eckbo and Thorburn (2009) ('Overall, the Swedish experience suggests that greater reliance on the auction mechanism, seen recently also in the U.S., enhances economic efficiency.'). See also Balz (2001).
} 
There are probably only two practically relevant considerations that suggest undertaking a restructuring in the form of a 'structured bargaining process' as opposed to a going-concern sale. First, it may be that the legal entity that runs the business owns 'dedicated assets' that cannot (easily) be transferred to a new legal entity (see Sect. 3.1 supra). However, it has been argued that such assets are much less important for today's businesses than they were in the 'age of the railroads'. 45 More importantly, under the European rules concerning the division of public limited liability companies, ${ }^{46}$ many Member States allow divisions by the formation of new companies to which all the assets and liabilities of the distressed legal entity (private or public limited liability company) are transferred. Hence, the presence of 'dedicated assets' should not, normally, be a compelling reason to advocate a structured bargaining process instead of a going-concern sale.

Second, in exceptional circumstances there may be no market for distressed firms. This may be the case, for example, because the industry in which the firm operates is depressed or because the financial (and economic) system is in a general crisis mode, drying up financing for investments. ${ }^{47}$ In such a setting, a goingconcern sale might risk selling the business at 'fire sale' prices, and indeed on a break-up basis, producing a result equivalent to liquidation (i.e., the loss of goingconcern value). But this surely is an exceptional setting.

By completely ruling out a going-concern sale of the distressed business to an investor, the European Commission eliminates a tried and tested restructuring tool, which now dominates the US restructuring practice, and which, absent extreme circumstances, is probably a much more efficient route to maximising the firm's net asset value for the benefit of its creditors.

\subsubsection{A Twisted and Truncated Insolvency Proceeding}

Finally, the draft RD is flawed as it constitutes a confused and incomplete insolvency proceeding. The European Commission's proposal is presented as a 'preventive restructuring framework' and is not meant to be an 'insolvency procedure' (as defined in Article 2(1) of the draft RD). Indeed, quite to the contrary, the framework states that it shall enable debtors in financial difficulty 'to restructure their debts or business, restore their viability and avoid insolvency' (Article 4(1) emphasis added). Further, Member States are charged with putting in place provisions 'limiting the involvement of a judicial or administrative authority to where it is necessary and proportionate so that rights of any affected parties are safeguarded' (Article 4(4)—emphasis added). The proceeding also gets going without court involvement (as noted above), and negotiations on a restructuring plan take place preferably in quiet, amongst professional financial investors and sophisticated debtors. Hence, what the Commission has in mind is, in essence, a

\footnotetext{
45 See Baird and Rasmussen (2002), at pp 758 et seq. For a different view, see Miller and Waisman (2005).

46 Sixth Council Directive of 17 December 1982 based on Article 54(3)(g) of the Treaty, concerning the division of public limited liability companies (82/891/EEC), OJ L 378 of 31 December 1982, p 47.

47 See, for example, Shleifer and Vishny (1992).
} 
workout or out-of-court restructuring ${ }^{48}$ with minimalistic rules to discipline holdouts-a speedy and, hopefully, consensual financial restructuring to give the distressed business some more (financial) breathing space.

However, this is only how the proposal is framed. If an American reader studies the draft RD, he or she will probably think that it looks quite similar to a full-blown Chapter 11 proceeding - almost, that is. Like a US-style Chapter 11 proceeding, there are detailed rules on class formation, there is the best interest of creditors test, a cross-class cram-down, sophisticated valuation techniques, rules on staying creditors' actions (and on executory contracts and ipso facto clauses) and on the protection of interim and new finance-to give but a few examples.

But, at the same time, certain crucial elements of a statutory restructuring proceeding are missing. The draft RD is silent, for example, on the ranking of claims and the protection of secured creditors. It is also silent on the problem of undervalue transactions in the vicinity of a preventive restructuring, and it does not contain rules on fraudulent transfers or avoidance actions. ${ }^{49}$ It privileges workers' claims (Article 6(3)), including, it seems, pension liabilities, even though a restructuring of SMEs in particular will often not be feasible without including these claims.

Taken together, the Commission's regulatory course seems twisted. The Commission started out to regulate workouts ('preventive restructurings') because it anticipated too much political resistance were it to venture into insolvency territory in a more narrow sense and embark on a harmonisation of Member States' corporate insolvency regimes. Then it noticed that it could not properly regulate workouts and, in particular, majority decision-making on a restructuring plan without putting in place judicial (or administrative) safeguards to protect the interests of affected creditors. Hence, it picked from the Chapter 11 machinery those tools it deemed tried and tested to administer a contested structured bargaining process on a restructuring plan. But these tools do not work properly in isolation. They are embedded in a sophisticated overall framework. At the centre of this framework is a strong bankruptcy court that is active from day one and oversees the proceeding, maintaining transparency and legitimacy to achieve a fair outcome. These tools require such a framework to function.

No such arbiter is contemplated by the Commission's proposal. A 'practitioner in the field of insolvency law' may or may not be appointed (Article 8(2) and (3)). A judicial or administrative authority comes into play only in the final act of the process when negotiations on a consensual restructuring plan have broken down, certain affected parties dissent, and the parties are in the midst of bitter valuation fights. Further, no tools are available to correct fraudulent behaviour in the vicinity of the preventive restructuring filing or undervalue transactions. In essence, the Commission proposes a twisted and truncated Chapter 11-style insolvency proceeding, not a 'preventive restructuring framework'.

To sum up: the Commission's proposal is flawed because it creates a refuge for failing firms that should be liquidated. The overwhelming majority of firms in financial distress fall into this category. The Commission's proposal is flawed

\footnotetext{
48 On workouts, see, for example, Roe (2000), at pp 399 et seq.; Eidenmüller (1999).

49 For the importance of fraudulent transfer rules see, e.g., Baird (2006), at pp 153 et seq.
} 
because it rules out going-concern sales for viable firms. Such sales are usually a much more efficient process to restructure viable firms and keep them alive. Finally, the Commission's proposal is flawed because it is, in essence, a twisted and truncated insolvency proceeding. It looks like a Chapter 11 proceeding but without strong court involvement from the beginning and without the tools needed for the court to guarantee a fair outcome of the process. Member States would not be able to remedy these fundamental design defects of the RD if it were adopted by the European Union as proposed.

Will the proposed 'preventive restructuring framework' be a fast and cheap method to resolve financial distress? That is very unlikely. Courts or competent 'administrative authorities' have to filter out non-viable firms — which will be difficult. They will have to undertake sophisticated company valuations when a restructuring plan is contested-not an easy task. And they will be equipped with judges/administrators who might be willing to learn fast (best interest of creditors test, cross-class cramdown, etc.) but lack the experience, knowledge and, importantly, tools (avoidance actions, etc.) to act efficiently and professionally. Institutions matter, and the judicial institutions in many Member States are not in a position to apply a 'preventive restructuring framework' as proposed by the European Commission. ${ }^{50}$

\subsection{The Misguided Harmonisation Plan}

Against this background, I now turn to critically examine the Commission's case for harmonising the Member States' laws based on the provisions in the draft RD. This case rests on a series on assumptions and assertions: (1) implementing the RD would reduce financing costs, especially for SMEs; (2) firms would, for the first time, get access to an efficient restructuring tool regardless of where in Europe they are located; and (3) the total volume of non-performing loans in Europe could be reduced, giving banks more flexibility to finance profitable projects and firms. Each of these assertions is unfounded. ${ }^{51}$

\subsubsection{Rising Financing Costs}

If the Commission's proposal were implemented, financing costs for businesses would rise, and not fall as claimed by the Commission. There are two reasons for this: first, the Commission proposes an inefficient 'preventive restructuring framework' that, if implemented, would reduce the net assets available for distribution to the firm's creditors and, as a consequence, their recovery rates.

\footnotetext{
${ }^{50}$ It is telling that Tirado (2017), in his analysis of the new Spanish restructuring regimes, concludes that '[p]roceedings take too long and are too costly due to an inadequate institutional framework'. In his view, 'deficiencies of the institutional framework' are the main reason for the little success of the reforms so far.

51 The analysis in this section is much more critical of the Commission's proposal than the analysis in Eidenmüller and van Zwieten (2015), at pp 650 et seq., on the harmonisation initiative of the Restructuring Recommendation (supra n. 7). This is due to (1) the precise nature of the current harmonisation initiative, (2) the precise rules of the proposed 'preventive restructuring framework', and (3) the slight change in argument put forward by the Commission to support its proposal (the emphasis is now on purported reductions with respect to financing costs for businesses and a reduction of nonperforming loans).
} 
Second, the proposed framework is particularly bad for financial (secured) creditors who matter the most for businesses' financing costs.

\subsubsection{Lower Recovery Rates for All Creditors Assume for a moment that the} Commission's proposed 'preventive restructuring framework' is inefficient in the sense that it lowers the net assets available for distribution to the firm's creditors compared to a more efficient procedure (e.g., liquidation, going-concern sale, etc.). How would that affect the recovery rates of creditors, and how would these recovery rates in turn affect the financing costs of businesses?

If the net assets available for distribution to the firm's creditors shrink compared to an alternative procedure, this does not necessarily mean that the recovery rates for all creditors would be lower. This would depend on the applicable distribution rules in the respective procedures. If, in a particular jurisdiction, these distribution rules are the same for all types of insolvency or restructuring procedures on offer, what can safely be said is that nobody will be better off under the inefficient 'preventive restructuring procedure' and at least some creditors will be worse off. If secured creditors enjoy some form of priority position-which is a reasonable assumption to make-the creditor group that will suffer the most from an inefficient 'preventive restructuring framework' are the general unsecured creditors. If the inefficiency of the 'preventive restructuring framework' is so great that, for example, assets used as collateral lose part or all of their value, then the recovery rates for secured creditors will also be lower compared to a more efficient restructuring or insolvency regime.

To the best of my knowledge, no empirical studies exist that attempt to relate the recovery rates of general unsecured creditors to a business's financing costs. Two types of general unsecured creditors contribute to the financing of a business: suppliers who provide trade credit, and banks which extend (syndicated) loans to borrowers. It is safe to assume that if these two types of financiers are faced with lower recovery rates, they will reduce the volume of credit and/or change the credit terms to the disadvantage of the borrower, increasing the borrower's financing costs. $^{52}$

However, we do have empirical evidence on how a different treatment of secured creditors in different European jurisdictions affects lending practice. Using a sample of small firms that defaulted on their bank debt in France, Germany and the United Kingdom, Davydenko and Franks found that significant differences in creditors' rights across Member States lead banks to adjust their lending and reorganisation practices to mitigate costly aspects of bankruptcy law. For instance, the authors found that 'French banks respond to a creditor-unfriendly code by requiring more collateral than lenders elsewhere, and by relying on collateral forms that minimise the statutory dilution of their claims in bankruptcy'. ${ }^{53}$ Hence, reducing the recovery rates for secured creditors raises the financing costs for borrowers.

\footnotetext{
52 Ways to test this hypothesis would be to look into the demand for, and volume of, trade insurance in jurisdictions with different recovery rates for trade creditors or into the loan covenants in syndicated loans extended to borrowers located in jurisdictions with different recovery rates for general unsecured creditors.

53 Davydenko and Franks (2008).
} 
Now I should like to return to the assumption made at the beginning of this section, namely that the Commission's proposed 'preventive restructuring framework' is inefficient in the sense that it lowers the net assets available for distribution to the firm's creditors compared to a more efficient procedure, such as, among other things, liquidation and a going-concern sale. My analysis and evaluation of the proposal were based on the design defects that Member States would not be able to remedy when implementing the RD. I found that the Commission's proposal is flawed because it creates a refuge for failing firms that should be liquidated, because it rules out going-concern sales for viable firms, and because it is, in essence, a twisted and truncated insolvency proceeding. As a consequence, the Commission's hope that its 'preventive restructuring framework' would increase creditors' recovery rates is wishful thinking. It will have the opposite effect: restructuring firms that should be liquidated, restructuring viable firms instead of using more efficient going-concern sales, and doing all this in a seriously deficient procedural framework will surely lower the recovery rates for all creditors.

3.3.1.2 Weak Position of Secured Creditors in Particular The Commission's proposal is primarily concerned with SMEs: 'The preferred option will reduce barriers for providing cross-border credit to SMEs: efficient restructuring would enable SMEs who are creditors to recover more than they would if the debtor entered insolvency. ${ }^{54}$ The most important source of financing for SMEs is bank lending on a secured basis. SMEs are usually not eligible for unsecured (syndicated) loans, and they rarely have access to bond finance.

We know that the treatment of secured creditors in insolvency proceedings influences lenders' behaviour and financing costs, and we know that, because of the general inefficiency of the proposed 'preventive restructuring framework', secured lenders' recovery rates will certainly not be higher-and possibly even lower-than in alternative, more efficient regimes (e.g., liquidation, going-concern sale, etc.see Sect. 3.3.1.1 supra).

On top of this now come the specific rules of the Commission's 'preventive restructuring framework' (or lack thereof) that have a direct effect on the position of secured financial creditors such as banks under the framework. It should be recalled that (1) the proposal is silent on the ranking of claims and on whether secured creditors enjoy a priority position; (2) a stay of up to twelve months may be imposed on creditors, including secured creditors, without further conditions such as interest payments, etc.; (3) creditors, including secured creditors, may not use ipso facto clauses to terminate or otherwise modify executory contracts; and (4) creditors, including secured creditors, may be forced to accept a restructuring plan that reduces their claims to what they would receive in a liquidation according to theunspecified-general ranking order of claims (see (1)).

Even if a Member State granted secured creditors a priority position when implementing the $\mathrm{RD}$, the prospect for secured creditors under the proposed preventive restructuring regime looks fairly grim. It is fanciful to assume that financing costs for SMEs could and would be lower under the proposal compared to

$54 \operatorname{COM}(2016) 723$ final, at p 19. 
alternative insolvency/restructuring regimes - the opposite is true. ${ }^{55}$ This assessment is consistent with the available empirical evidence. In 2012, Rodano, SerranoVelarde and Tarantino found that the introduction of a reorganisation procedure increased the interest rates on bank loans. ${ }^{56}$

\subsubsection{Inefficiency on a European-Wide Scale}

The Commission's harmonisation argument also relies on the assertion that under the proposed framework European firms, especially SMEs, would, for the first time, get easy access to an efficient restructuring tool regardless of where in Europe they are located. This claim is also unfounded, for several reasons.

First, while it is true that forum shopping for an efficient restructuring regime is relatively cheaper (and easier) for large firms than for SMEs, it is not true that in the past smaller firms were prevented from accessing foreign insolvency or restructuring proceedings either by shifting their Centre of Main Interests (COMI) under the EIR or by making use of foreign proceedings that are not within the scope of the EIR and that, therefore, can be accessed without a COMI shift. The English Scheme of Arrangement in particular has been successfully used to restructure foreign SMEs. ${ }^{57}$

Second, forum shopping by some European firms for the best (most efficient) insolvency or restructuring regime has put regulatory pressure on the Member States to make their domestic regimes more competitive. ${ }^{58}$ As already mentioned in the introductory Sect. 1 of this paper, Member States of the European Union are already experimenting with various types of pre-insolvency or preventive restructuring proceedings that aim at refinancing financially distressed but economically viable firms. Germany, for example, undertook a fundamental modernisation of the restructuring section of its Insolvency Statute (Insolvenzordnung) in 2012. The draft bill of the German government cited forum shopping by German firms for foreign proceedings as one of the main drivers of the reform. ${ }^{59}$ Hence, a competitive dynamic towards putting in place more efficient restructuring/insolvency frameworks is already operating in Europe, forcing Member States to adopt models that have proven successful in other jurisdictions-put another way, a 'hands-off' approach by the Commission is much more likely to lead to (efficient) harmonised restructuring/insolvency frameworks across Member States than the Commission's present proposal.

\footnotetext{
55 It is irrelevant for this assessment that Article 8 of the recast EIR protects rights in rem under certain circumstances (they must be situated in another Member State than that in which insolvency proceedings are opened). This protection is afforded to all insolvency proceedings within the scope of the EIR.

56 Rodano et al. (2012).

57 See Payne (2013).

58 See Eidenmüller (2011), at pp 724-725.

59 See Deutscher Bundestag, Drucksache 17/5712 of 4 May 2011, p 17: 'In der Vergangenheit haben einige Unternehmen deshalb ihren Sitz nach England verlegt, da der Geschäftsleitung und den maßgeblichen Gläubigern die Eröffnung eines Insolvenzverfahrens nach englischem Recht zur Sanierung des Unternehmens vorteilhafter erschien. Auch wenn dies Einzelfälle geblieben sind, so haben sie doch Anstoß zu einer umfassenden Diskussion in der Fachöffentlichkeit über den Sanierungsstandort Deutschland gegeben und den Blick für die Schwächen des geltenden deutschen Rechts geschärft.'
} 
Third, and most importantly, the Commission's 'preventive restructuring framework' is an inefficient procedure, as has been demonstrated in Sects. 3.2 and 3.3.1.1 supra. If implemented by the Member States, the RD would give SMEs domestic access to an inefficient regime and not to a regime that leads to higher recovery rates. What is worse, the RD would prevent Member States from experimenting with more innovative and potentially much more efficient insolvency and/or restructuring regimes. Given that the RD's regime consists of binding minimum harmonisation rules, there is nothing that Member States can do with respect to financially distressed firms' pre-insolvency that departs from the Commission's framework. The Commission is about to create an inefficient restructuring framework on a European-wide scale with no opportunity for Member States to 'experiment themselves out' of the harmonised regime that they are forced to implement. Moreover, if the regime falls within the scope of the (recast) EIR, as planned by the Commission, its effects would have to be automatically recognised in all Member States. ${ }^{60}$ The opportunity costs of the Commission's harmonisation project are thus significant.

\subsubsection{More Written-off Loans}

Finally, the Commission justifies its proposal with the assertion that its application in the Member States could reduce the total volume of non-performing loans in Europe, giving banks more flexibility to finance profitable projects and firms. Again, this is wishful thinking. If it is correct that the Commission's 'preventive restructuring framework' is deeply flawed and inefficient, attracting economically failing firms like the light attracts mosquitoes, and if it is also true that it prevents Member States from experimenting with more value-preserving restructuring/ insolvency regimes, then what we can expect is not fewer non-performing loans but more (completely) written-off loans.

To sum up: the Commission's harmonisation plan is misguided. If implemented, financing costs for firms would rise because recovery rates for creditors would be lower compared to more efficient procedures (e.g., liquidations, going-concern sales, etc.) and, more specifically, because secured creditors in particular would have a weak position under the proposed 'preventive restructuring framework'. The RD, if implemented by the Member States, would cast in stone an inefficient restructuring framework on a European-wide scale. It would prevent Member States from experimenting with more efficient procedures and it would lead to more written-off loans instead of fewer nonperforming loans. The Commission should withdraw its proposal.

\section{An Alternative Regulatory Proposal}

In the following, I will develop an alternative regulatory proposal. The key feature of this proposal is that European firms would be allowed to opt into a European Insolvency Regime in their charter. This regime would be embodied in a European Regulation, rather than a Directive.

\footnotetext{
60 This point was made already by Eidenmüller and van Zwieten (2015), at pp 649-650.
} 


\subsection{Opting into a European Insolvency Regime}

The idea of contracting for bankruptcy rules is not new. Indeed, it has been suggested by scholars for decades. ${ }^{61}$ The main purpose of the idea is to privatise bankruptcy to the extent possible, capitalising on the informational advantage and creativity of private actors to identify and implement efficient regimes to resolve financial distress. The simplest and most promising of the suggested models is to let firms choose an insolvency regime in their charter. ${ }^{62}$ If this were feasible, everyone (voluntarily) transacting with the firm would know what to expect if the firm were forced to file for insolvency. There are certain 'technical' issues with this approach, in particular the question of how to deal with charter amendments, but these can be 'solved' (see infra).

The main regulatory problem of allowing firms to opt into an insolvency regime in their charter is that the applicable state law needs to permit such a choice. Although the 'opt in' concept was developed in the US, US law has not permitted and still does not permit such choice. Fortunately, the regulatory environment in Europe is different, and the European lawmaker has tools to allow firms to contract for a European Insolvency Regime. Indeed, the European lawmaker has already used these tools in other areas of the law. For example, it created the 'Societas Europaea' (SE), through a European Regulation. ${ }^{63}$ The SE is a 'European' company law form for public corporations. Under the relevant Regulation, European firms can re-incorporate as an SE and, in fact, many have done so in the last years: as of 6 January 2017, there were 2,672 SEs in the European Union, ${ }^{64}$ the majority of which being located in the Czech Republic and Germany. ${ }^{65}$ Major listed companies such as the German insurer Allianz, the chemical company BASF and energy suppliers such as E.ON and BP Europe are all incorporated as SEs.

Even closer to the present regulatory problem, the European lawmaker suggested an optional Common European Sales Law (CESL) a couple of years ago. ${ }^{66}$ If it had been implemented, it would have provided businesses and consumers with the option to submit particular transactions to a genuinely European contract law regime, embodied in a European Regulation. In the end, the proposal was rejected for political reasons, one of them being that (some) consumer organisations feared that the proposed legislation would enable traders to avoid national mandatory consumer protection where national laws of Member States were stronger than the CESL, thus weakening protection for consumers. However, the underlying

\footnotetext{
61 Pioneering work has been done by Rasmussen (1992) and Rasmussen (1997). See also Schwartz (1998), Warren and Westbrook (2005) and Eidenmüller (2005).

62 Rasmussen (1992, 1997).

63 Council Regulation (EC) No 2157/2001 of 8 October 2001 on the Statute for a European company (SE), OJ L 294 of 10 November 2001, pp 1 et seq.

64 See http://ecdb.worker-participation.eu/ (last visited on 6 January 2017).

65 For the reasons, see Eidenmüller et al. (2009) and Eidenmüller and Lasák (2012).

66 Proposal for a Regulation of the European Parliament and of the Council on a Common European Sales Law, COM(2011) 635 final of 11 October 2011. On the proposal see, for example, Eidenmüller (2013).
} 
regulatory idea was intelligent and sound: give market participants more choice, and let them decide on the success and failure of 'legal products'.

That same idea can be applied to the realm of restructuring/insolvency law. The European lawmaker could allow European corporations to opt into a European restructuring/insolvency regime in their corporate charter. This regime would be embodied in a European Regulation. ${ }^{67}$ Compared to a Directive, a Regulation has the advantage that its provisions are directly applicable in all Member States. Further, the Regulation would contain a restructuring/insolvency regime that is complete ('fully specified'). Thus, it would avoid gaps and ambiguities to the greatest extent possible, such that it could be executed by national courts without further domestic implementing rules. Those transacting with a corporation would then have the advantage of understanding exactly what their rights are should the company file for a statutory restructuring/insolvency proceeding, and thus be able to price credit extended to the firm accordingly.

Of course, the experience with the SE Regulation shows that this might not be fully achievable. Member States might press for options to choose from when applying the restructuring/insolvency Regulation to companies registered in their jurisdiction, and the Regulation might contain 'hidden gaps' unnoticed by the European lawmaker. However, striving for maximum completeness is important especially against the background of the very different approach of the draft RD, an instrument which will not lead to a harmonised legal position in the Member States (see Sect. 2, last paragraph supra).

On top of the possibility to opt into the substantive rules of a European restructuring/insolvency Regulation, the European lawmaker could give firms the option to have that Regulation enforced by a specialised European insolvency court. This could be an interesting and desirable feature of the option especially for firms registered in jurisdictions with serious deficiencies in their institutional (administrative/judicial) framework.

The great advantage of having an optional European restructuring/insolvency regime in place is that it preserves horizontal regulatory competition between the Member States for the best restructuring/insolvency 'product' and adds a vertical dimension to that regulatory competition: private actors would then have an additional restructuring/insolvency regime they can use, and this regime could possibly even be enforced by a specialised European insolvency court. If the European regime turns out to be attractive, Member States will have strong incentives to modernise their domestic regimes, copying features of the successful European model. If the European regime fails, it simply will not be used. But, in any

\footnotetext{
67 This precise regulatory technique was not considered in the impact assessment prepared by Hausemer et al. for the European Commission when considering the model of a $29^{\text {th }}$ option, see Hausemer et al. (supra n. 16), at pp 64-65, 74-77. Hence, the authors arrive at a completely erroneous conclusion: 'The main drawback of a 29 th regime is that it would not be clear at the time of the investment which restructuring regime would apply (the 29th regime or one of the national regimes). In addition, the creation and implementation of such a regime would take a long time, which in turn would mean that any benefits would only accrue to companies in the longer term.' This is completely erroneous because (1) firms would opt for the regime in their charter, i.e., before a third party would invest; (2) implementation of the regime by a European Regulation that can be chosen would probably be much faster and create much more legal certainty than harmonisation of Member States' laws via a European Directive.
} 
case, it will not be a system that creates mandatory European-wide inefficiencies, like the draft RD, if adopted, would. Likewise, it will not block Member States' incentives and freedom to experiment with new, potentially more efficient procedures-again, as is the case for the draft RD. Given that Member States' domestic insolvency regimes would be untouched by the European regime, one could also expect less political resistance to such an instrument compared to a harmonisation Directive that forces Member States to adopt certain rules and standards.

If firms were to opt for the European regime in their charter, the process could rightfully be characterised as 'contracting for a European Insolvency Regime' vis-àvis the firm's voluntary transaction partners, i.e., for those with contractual claims against the firm: when dealing with the firm they would know what to expect should the firm file for insolvency, and they could adapt contract terms accordingly. Of course, some transaction partners of the firm would not, given the (small) size of their claims, bother to do so. And other, non-contractual claimants, such as tort creditors, clearly could not be said to have consented to the firm's choice(s) at all. Yet, the difficulties concerning non-adjusting and/or involuntary creditors are not insurmountable. Rather, the European lawmaker can design an (efficient) instrument that takes account of, and/or makes particular provision for, non-adjusting and/or involuntary creditors.

Finally, firms might wish to change their initial choice of the European regime and revert to the legal position that would apply had they not chosen it. That legal position would, under the (recast) EIR, be determined by the location of their COMI. A rebuttable presumption in the EIR points to the laws in the jurisdiction where the place of the registered office of the company is located (Article 3 EIR). Conversely, firms might wish to opt out of their domestic restructuring/insolvency regime in the course of their lifecycle. The European lawmaker could permit such midstream choices, and safeguards could and would need to be established to prevent any opportunistic last-minute changes. However, the recast EIR already contains a good model for how this could be achieved: according to Article 3(1), paragraph 2 of the recast EIR, the presumption that a firm's COMI is determined by the place of its registered office 'shall only apply if the registered office has not been moved to another Member State within the 3-month period prior to the request for the opening of insolvency proceedings'. That provision could, mutatis mutandis, also be applied with respect to midstream choices of the applicable restructuring/ insolvency regime in a firm's charter.

\subsection{Principles of an Efficient European Insolvency Regime}

This is not the place to draft a 'European Insolvency Regime' cast in the legal form of a European Regulation. Still, I would like to formulate at least some important principles that, in my view, should guide the design of such an instrument. This seems all the more necessary as the draft RD contains fundamental design flaws that should be avoided when proposing an optional 'European Insolvency Regime' in the form of a European Regulation. 


\subsubsection{Openness to Restructurings, Going-Concern Sales, and Liquidations}

First, the procedure should be open to restructurings, going-concern sales, and liquidations. Two of the major design flaws of the draft RD are that it is biased towards preserving firms that should be liquidated and that it is biased towards restructurings as opposed to potentially more efficient forms of value preservation such as goingconcern sales. Thus, the European instrument should contain a filter that channels nonviable firms to a liquidation and viable ones to a going-concern sale unless there are compelling indicators that maximising the net assets available for distribution to the firm's creditors mandates a restructuring (e.g., the presence of non-transferable 'dedicated assets', lack of sufficient investor interest in a going-concern sale, etc.).

To this effect, an independent examiner could be appointed by the competent court immediately upon the filing of a petition to initiate the proceeding, and charged with the task of examining and certifying the economic viability of the petitioning firm. ${ }^{68}$ This would enable the filtering of viable from non-viable firms very early on in the process through the use of an independent specialist who is supervised by the competent court. The examiner could also advise on the valuemaximising form of maintaining the firm as a going concern (going-concern sale or restructuring) and other important insolvency-related matters, such as monitoring the financial affairs of the debtor.

\subsubsection{Fully Specified and Fully Collective Proceeding}

Second, the proceeding should be fully specified, and should also be fully collective, reaching out to all of the firm's creditors. 'Full specification' means that the procedure should be a complete insolvency proceeding, addressing all the problems as typically arise in a business insolvency. Unlike the draft RD, the proceeding should include, for example, rules on the ranking of claims and on fraudulent transfers or undervalue transactions prior to the filing. A strong and competent arbiter also needs to be in place and active right from the very start to guarantee that the proceeding's rules are followed and due process is observed. Clearly, it would correspond to the tradition of European and American insolvency systems to put courts and not, as suggested in the draft RD, 'administrative authorities' in this position. $^{69}$

Further, the proceeding should be fully collective in the sense that the enforcement of the claims of all creditors is interfered with, for example, by a universal stay or by the possibility to impose substantive modifications to creditor entitlements to which all creditors, in principle, are subject even if they dissent. ${ }^{70}$ The reason for this stipulation is that, in a cross-border context, only 'fully collective' proceedings merit, from a normative perspective, immediate universal recognition such that they can override legitimate creditor expectations with respect to dispute resolution forum and governing law. Evidently, it is crucial for the new

\footnotetext{
$\overline{68}$ For this proposal, see Eidenmüller and van Zwieten (2015), at p 658.

69 See Eidenmüller (2016a), Section V.

70 See Eidenmüller (2016b).
} 
'European Insolvency Regime' to 'deserve', once an opening decision is given by a competent court, automatic universal recognition under Article 19(1) EIR.

\subsubsection{DIP Proceeding with Supervisor}

One crucial feature of an efficient insolvency proceeding is that it motivates debtors to access the proceeding earlier rather than later. The earlier restructuring measures are implemented, the higher the (remaining) going-concern value of the firm will be (see Sect. 3.1 supra). This implies that neither an insolvency requirement, nor even a 'likelihood of insolvency' test should be stipulated as an entry requirement for the proceeding. ${ }^{71}$ This follows since debtors usually do not file for an insolvency proceeding without any signs of financial distress, given the direct and indirect costs associated with the proceeding for the business and the possibility that it will be liquidated in the process. In those rare cases in which abuse is an issue, ${ }^{72}$ the competent court can step in and declare an abusive filing to be ineffective.

Thus, in order to give firms a strong incentive to file as early as reasonably possible under the circumstances, the insolvency proceeding should be run in DIP form, i.e., without the appointment of an insolvency practitioner who would take over key managerial functions as soon as the firm files the petition to initiate the process. If the debtor firm has certainty that the proceeding will be conducted in DIP form, it has a strong incentive to access it in a timely fashion. ${ }^{73}$ A carrot that incentivises the best, most informed and familiar actors to engage the process should be more effective than liability rules for a belated filing.

Further, and unlike under US law, the DIP proceeding should always lead to the appointment of a supervisor by the competent court, who would be tasked with examining the economic viability of the petitioning firm (see Sect. 4.2.1 supra) and other insolvency-related functions. ${ }^{74}$ The supervisor would have to safeguard the interests of all creditors in the process. A neutral third party appears needed to prevent the par conditio creditorum from being undermined by dominant financial creditors prior to the filing of the petition or during the insolvency process.

In sum, the proceeding suggested here as an optional 'European Insolvency Regime' would resemble, to a large degree, a US Chapter 11 proceeding. However, there would at least be one crucial, structural difference: the proceeding would always lead to the appointment of a supervisor who would fulfil crucial tasks such as opining on the viability of the business and the preferred course of action (restructuring, going-concern sale, liquidation). A significant governance role exercised by an independent and professional insolvency practitioner conforms more to the European regulatory tradition than an 'unbound DIP' as in the US. ${ }^{75}$

\footnotetext{
71 This point was made already by Eidenmüller and van Zwieten (2015), at pp 660-661.

72 See, for example, Eidenmüller (2014).

73 Of course, that does not guarantee the incumbent management's position upon or after filing: given that the filing firm will usually be cash-poor, financial creditors will have leverage to initiate changes in top management positions, and experience shows that they use this leverage if needed.

${ }^{74}$ For this proposal, see Eidenmüller and van Zwieten (2015), at p 659.

75 See Eidenmüller (2016a), Section V.
} 
Whether this suggestion would improve Chapter 11 is certainly up for debate. But it clearly is better than the twisted and truncated Chapter 11 model proposed by the European Commission in its draft RD.

\section{Summary and Outlook}

The European Commission has made a significant move to harmonise parts of Member States' insolvency laws. It has proposed a Directive on pre-insolvency 'preventive restructuring frameworks' - the draft RD. If adopted, the RD would force the Member States to design restructuring proceedings that conform to the Directive's stipulations. The European Commission hopes that this would lower financing costs for European firms and give SMEs, in particular, access to local and efficient restructuring regimes.

In this paper, I have argued that the Commission's regulatory approach is misguided and that the proposed 'preventive restructuring framework' is seriously deficient. The Commission should withdraw its proposal. I have also suggested an alternative regulatory approach: European firms should be given the option to choose a 'European Insolvency Regime' in their charter. This regime should be embodied in a European Regulation. I have outlined the main principles for its design. The main results of this paper can be summarised as follows:

1. The Commission's proposal of a 'preventive restructuring framework' is flawed because it creates a refuge for failing firms that should be liquidated. The overwhelming majority of firms in financial distress fall into this category. The Commission's proposal is also flawed because it rules out going-concern sales for viable firms. Such sales are usually a much more efficient process to restructure viable firms and keep them alive. Finally, the Commission's proposal is flawed because it is, in essence, a twisted and truncated insolvency proceeding. It looks like a Chapter 11 proceeding but without strong court involvement from the beginning and without the tools needed for the court to guarantee a fair outcome of the process.

2. The Commission's harmonisation plan is misguided. If implemented, financing costs for firms would rise because recovery rates for creditors would be lower compared to more efficient procedures (e.g., liquidations, going-concern sales, etc.) and, more specifically, because secured creditors in particular would have a weak position under the proposed 'preventive restructuring framework'. The $\mathrm{RD}$, if implemented by the Member States, would cast in stone an inefficient restructuring framework on a European-wide scale. It would prevent Member States from experimenting with more efficient procedures, and it would lead to more written-off loans instead of fewer non-performing loans.

3. European firms should have the option to choose a 'European Insolvency Regime' in their charter. This regime should be embodied in a 'fully specified' (complete) European Regulation, guaranteeing legal certainty to stakeholders. Firms might be given the additional option to have this regime enforced by a specialised European insolvency court. Firms need not opt into the European 
regime and could stick to their domestic insolvency regimes. Hence, horizontal regulatory competition between the Member States for the best insolvency product' would be preserved, and a new, vertical regulatory competition between the Member States and the EU would be introduced in the field of insolvency law.

4. Key design features of the proposed optional 'European Insolvency Regime' are the following: (1) it should be open to restructurings, going-concern sales, and liquidations-firms should be channelled into the appropriate process based on the opinion of a court-appointed supervisor; (2) it should be a fully specified (complete) and fully collective insolvency proceeding; and (3) the proceeding should be conducted in DIP form with the mandatory appointment of a supervisor who performs important insolvency-related functions.

If the European lawmaker were to change course and proceed as suggested in this paper, this would certainly mean more insolvency — and not just 'pre-insolvency' regulation in a narrow sense than it had planned to introduce initially. At the same time, the draft RD is not a mere 'preventive restructuring framework'. It is, in essence, a dysfunctional insolvency proceeding. Indeed, the European lawmaker does not inspire confidence through its attempts 'to sell' Member States legal instruments under a misleading heading.

By contrast, the proposal developed in this paper claims to be a proposal for an insolvency proceeding, and that is precisely what it is. Nevertheless, given its optional character, it in no way infringes the regulatory traditions of the Member States or restricts their freedom to experiment with even more modern/creative proceedings. If the proposal developed in this paper is a failure, it simply will not be selected by firms, sending a signal to the European lawmaker to develop a better product. In this sense, the risk is low.

Finally, the analysis in this paper sheds a critical light on the European tendency mentioned in the introductory section to regulate out-of-court restructurings (workouts) by introducing sophisticated 'pre-insolvency restructuring frameworks'. As the draft RD amply shows, once you start thinking about disciplining holdouts by sophisticated pre-insolvency restructuring proceedings, these proceedings quickly become complex and complicated. On the margin, they more or less resemble fullblown insolvency proceedings. But then the advantages of workouts, i.e., greater flexibility, lower costs, possibly even confidentiality, are lost.

It may be a preferable regulatory strategy to preserve the fully informal character of workouts and have full-blown insolvency proceedings as a backup-in the shadow of which the workout is negotiated. This is, of course, how things are done on the other side of the Atlantic. To add some European ingredient to this, one could allow the courts to step in and discipline holdouts by imposing 'cooperation duties' on them in extreme cases. ${ }^{76}$ But that is another story.

Acknowledgements I should like to thank the participants in the ECGI/Columbia/Oxford Conference 'The Future Framework for European Capital Markets: Law and Finance' on 13/14 January 2017 for

76 See Eidenmüller (2006), at pp 254 et seq. 
helpful comments. Special thanks for detailed comments go to Sarah Paterson. I should also like to thank Conor McLaughlin, Jack Maslen and Tilmann Frobenius for helpful feedback on an earlier draft.

Open Access This article is distributed under the terms of the Creative Commons Attribution 4.0 International License (http://creativecommons.org/licenses/by/4.0/), which permits unrestricted use, distribution, and reproduction in any medium, provided you give appropriate credit to the original author(s) and the source, provide a link to the Creative Commons license, and indicate if changes were made.

\section{References}

Adler B, Chapkun V, Weiss L (2006) Destruction of value in the new era of Chapter 11. Available at http://homes.chass.utoronto.ca/ szhou/print/NewEraCh11.pdf. Accessed 4 Jan 2017

Ayottee K, Morrison E (2009) Creditor control and conflict in Chapter 11. J Legal Anal 1:511-551

Baird D (1986) The uneasy case for corporate reorganizations. J Legal Stud 15:127-147

Baird D (2006) Elements of bankruptcy, 4th edn. Foundation Press, New York

Baird D, Rasmussen R (2002) The end of bankruptcy. Stanf Law Rev 55:751-789

Baird D, Rasmussen R (2003) Chapter 11 at twilight. Stanf Law Rev 56:673-699

Baird D, Rasmussen R (2010) Antibankruptcy. Yale Law J 119:648-699

Balz M (2001) Equity auctions and a new concept of priority: two bankruptcy reform proposals. Available at SSRN: https://ssrn.com/abstract=264511. Accessed 2 Mar 2017

Bebchuk L (1988) A new approach to corporate reorganizations. Harv Law Rev 101:775-804

Davydenko S, Franks J (2008) Do bankruptcy codes matter? A study of defaults in France, Germany, and the UK. J Finance 63:565-608

Eckbo B, Thorburn K (2009) Economic effects of auction bankruptcy. Available at SSRN: https://ssrn. com/abstract=1387347. Accessed 8 Jan 2017

Eidenmüller H (1999) Unternehmenssanierung zwischen Markt und Gesetz: Mechanismen der Unternehmensreorganisation und Kooperationspflichten im Reorganisationsrecht. Otto Schmidt, Köln

Eidenmüller H (2005) Free choice in international company insolvency law in Europe. Eur Bus Org Law Rev 6:423-447

Eidenmüller H (2006) Trading in times of crisis: formal insolvency proceedings, workouts and the incentives for shareholders/managers. Eur Bus Org Law Rev 7:239-258

Eidenmüller $\mathrm{H}$ (2011) The transnational law market, regulatory competition, and transnational corporations. Indiana J Glob Legal Stud 18:707-749

Eidenmüller H (2013) What can be wrong with an option? An optional Common European Sales Law as a regulatory tool. Common Mark Law Rev 50:69-84

Eidenmüller H (2014) Strategische Insolvenz: Möglichkeiten, Grenzen, Rechtsvergleichung. Zeitschrift für Wirtschaftsrecht (ZIP) 35:1197-1204

Eidenmüller H (2016a) Comparative corporate insolvency law. Available at SSRN: https://ssrn.com/ abstract $=2799863$. Accessed 1 Jan 2017

Eidenmüller H (2016b) What is an insolvency proceeding? Available at SSRN: https://ssrn.com/abstract= 2712628. Accessed 6 Jan 2017

Eidenmüller H, Engert A (2009) Reformperspektiven einer Umwandlung von Fremd- in Eigenkapital (Debt-Equity Swap) im Insolvenzplanverfahren. Zeitschrift für Wirtschaftsrecht (ZIP) 30:541-553

Eidenmüller H, Lasák J (2012) The Czech Societas Europaea puzzle. J Corp Law Stud 12:237-254

Eidenmüller H, van Zwieten K (2015) Restructuring the European business enterprise: the European Commission's Recommendation on a new approach to business failure and insolvency. Eur Bus Org Law Rev 16:625-667

Eidenmüller H, van Zwieten K (2016) The future of restructuring law in Europe: greater harmonisation, but at what cost? Oxf Bus Law Blog. Available at https://www.law.ox.ac.uk/business-law-blog/blog/ 2016/12/future-restructuring-law-europe-greater-harmonisation-what-cost. Accessed 4 Jan 2017

Eidenmüller H, Engert A, Hornuf L (2009) Incorporating under European law: the Societas Europaea as a vehicle for legal arbitrage. Eur Bus Org Law Rev 10:1-33 
Franks J, Loranth G (2005) A study of inefficient going concerns in bankruptcy. Available at SSRN: https://ssrn.com/abstract=774146. Accessed 8 Jan 2017

Lin Y, Rosenberg C (2013) Dealing with private debt distress in the wake of the European financial crisis: a review of the economics and legal toolbox. IMF Working Paper WP/13/44. Available at https:// www.imf.org/external/pubs/ft/wp/2013/wp1344.pdf. Accessed 8 Jan 2017

Lubben S (2004) The 'new and improved' Chapter 11. Ky Law J 93:839

Miller H (2002) Chapter 11 reorganization cases and the Delaware Myth. Vanderbilt Law Rev 55:1987-2018

Miller H, Waisman S (2005) Is Chapter 11 bankrupt? Boston Coll Law Rev 47:129-181

Paterson S (2015) Rethinking corporate bankruptcy theory in the twenty-first century. Oxf J Legal Stud 36:697-723

Payne J (2013) Cross-border schemes of arrangement and forum shopping. Eur Bus Org Law Rev 14:563-589

Payne J (2016) The future of UK debt restructuring. Available at SSRN: https://ssrn.com/abstract= 2848160. Accessed 22 Jan 2017

Rasmussen R (1992) Debtor's choice: a menu approach to corporate bankruptcy. Texas Law Rev 71:51

Rasmussen R (1997) A new approach to transnational insolvencies. Mich State J Int Law 19:1

Rodano G, Serrano-Velarde N, Tarantino E (2012) Bankruptcy law and the cost of banking finance. Available at http://www.sbs.ox.ac.uk/sites/default/files/Business_Taxation/Docs/WP1218.pdf. Accessed 8 Jan 2017

Roe M (2000) Corporate reorganization and bankruptcy: legal and financial materials. Foundation Press, New York

Roe M (2016) Three ages of bankruptcy. Available at SSRN: https://ssrn.com/abstract=2871625. Accessed 1 Jan 2017

Schultze \& Braun (2014) Insolvency and restructuring in Germany: Yearbook 2014. F.A.Z.-Institut, Achern and Frankfurt a.M. Available at http://www.schubra.de/en/publications/downloads/ Yearbook2014.pdf. Accessed 3 Jan 2017

Schwartz A (1998) A contract theory approach to business bankruptcy. Yale Law J 107:1807-1851

Shleifer A, Vishny R (1992) Liquidation values and debt capacity: a market equilibrium approach. J Finance 47:1343-1366

Skeel D (2001) Debt's dominion: a history of bankruptcy law in America. Princeton University Press, Princeton

Tirado I (2017) Out of court debt restructuring in Spain: a modernised framework. Paper presented at the conference 'The Scheme of Arrangement as a Debt Restructuring Tool' at the University of Oxford on 12 January 2017 (paper on file with author)

Warren E, Westbrook J (2005) Contracting out of bankruptcy: an empirical intervention. Harv Law Rev 118:1197-1254

White M (1996) The costs of corporate bankruptcy: a U.S.-European comparison. In: Bhandari J, Weiss L (eds) Corporate bankruptcy: economic and legal perspectives. CUP, Cambridge, pp 467-500 